\title{
Chromosome Studies in Some Members of Lupinus (Fabaceae: Lupininae) of South America
}

\author{
P. Perissé*, L. Torres and A. M. Planchuelo** \\ Facultad de Ciencias Agropecuarias Universidad Nacional de Córdoba, \\ C. C. 509 (5000) Córdoba, Argentina \\ Accepted January 24, 2000
}

\begin{abstract}
Summary Karyomorphology and somatic chromosomic numbers of 4 species of Lupinus were examined. The chromosome studies reveal for the first time the presence of $2 n=36$ chromosomes in 3 South American species (L. albescens Hook. et Arn., L. paraguariensis Chodat et Hassl., L. multiflorus Desr.). For the introduced species $L$. arboreus Sims., $2 \mathrm{n}=48$ was confirmed. The karyotype of L. albescens shows $15 \mathrm{~m}+3 \mathrm{sm}$ with the satellites in the short arms of the $\mathrm{m}$ pair 1 and, in the long arms of the sm chromosome pair 16. L. multiflorus shows $15 \mathrm{~m}+3 \mathrm{sm}$.
\end{abstract}

Lupinus is a large genus (ca. 600 species, Planchuelo 1994) of the Leguminosae that belongs to the tribe Genisteae, subtribe Lupininae (Bisbi 1981). It is primarily a New World genus that grows from Alaska to Tierra del Fuego Island (Planchuelo 1994). The lupin crop contributes to farming systems in different ways and is used for very different purposes: grain or pasture production in crop rotation, green manure, or soil conservation (Lopez-Bellido 1994).

Chromosomic characteristics such as chromosome number is a useful tool for identifying systematic relationships at the infrageneric level (Carstairs et al. 1992). The tribe Genisteae is the most cytologically complex in Leguminosae and Lupinus forms a rather isolated major group within this tribe (Goldblatt 1981). Although cytologycal studies related with the genus were made on either cultivated or native species of the Old World, only few chromosomic counts from species of South America are known (Federov 1974, Goldblatt and Johnsons 1990, 1991, 1994, 1996).

Records of the somatic chromosome numbers for Old World species are: L. angustifolius $\mathrm{L}$. (40), L. albus L. (50), L. luteus L., L. micranthus Guss. and L. hispanicus Boiss. et Reuter (52) (Gladstones 1974, Goldblatt 1981, Federov 1974), L. cosentinii Guss. (32), L. digitatus Forskal (36), L. princei Harns (38), L. pilosus Murray, L. palestinus Boiss (42) and L. atlanticus (38) (Carstairs et al. 1992).

The predominant somatic number registered for North American lupins is $2 n=48$ (Dunn 1984). Whereas less common numbers cited are $2 n=24,36,40$ and 96 (Federov 1974, Goldblatt 1981). The only species of South America cytologically studied are L. mutabilis Sweet. with $2 \mathrm{n}=48$ (Cerrate and Camarena 1981) and L. russellianus C. P. Smith with $2 \mathrm{n}=36$ (Federov 1974).

Since wild lupins constitute a source for genetic variability, there is a need to obtain more cytogenetic information for further studies on phylogeny relationships and phytogeographical distribution between cultivated species and their wild relatives.

Accordingly, the aim of this study was to document the somatic chromosomic number and the karyotype of South American species of Lupinus.

Three chromosomic numbers and two karyotypes are reported for the first time for 3 species and a previous report is confirmed.

* Corresponding author.

** Member of CONICET. 


\section{Materials and methods}

Seeds of native species where collected in North Eastern Argentina and Uruguay and the introduced one was obtain from the Andean Patagonic region of Argentina. Places of collection and specimen vouchers are as follow: L. albescens Hook. et Arn., Isla Timbó Santa Fé ( $\left.{ }^{\circ} 662\right) ; L$. paraguariensis Chodat et Hassl., Apóstoles, Misiones ( ${ }^{\circ}$ 672); L. multiflorus Desr., Dpto. Rocha, Uruguay ( $\left.\mathrm{N}^{\circ} 698\right)$; L. arboreus Sims, Villa La Angostura, Neuquén ( $\left.\mathrm{N}^{\circ} 1249\right)$. Vouchers are kept in the Herbarium (ACOR) of the College of Agriculture National University of Córdoba Argentina.

Mitotic metaphases were examined in root meristematic cells. Seeds were scarified and germinated on blotting paper in Petry dishes at $20^{\circ} \mathrm{C}$ for $72 \mathrm{~h}$. Root tips were cold treated during $17 \mathrm{~h}$ then fixed in lactic acetic acid $(1: 5)$ at room temperature overnight and then transferred to $-20^{\circ} \mathrm{C}$. After $24-48 \mathrm{~h}$ the root tips were hydrolyzed in $1 \mathrm{~N} \mathrm{HCl}$ at $60^{\circ} \mathrm{C}$ for $10 \mathrm{~min}$, then transferred to Schiff's reagent until root tips became stained. Squashes were made with $2 \%$ lacto-propionic-orcein. Photomicrographs were made in a Zeiss Axioscope Photomicroscope. Metaphasic chromosome lengths were determined with Vernier callipers from photography enlargements. No less than 5 cells per individual and 5 root tip squashes per species were examined under the microscope. Karyotypes were described on the basis of arm ratios and centromeric indexes (Levan et al. 1964).
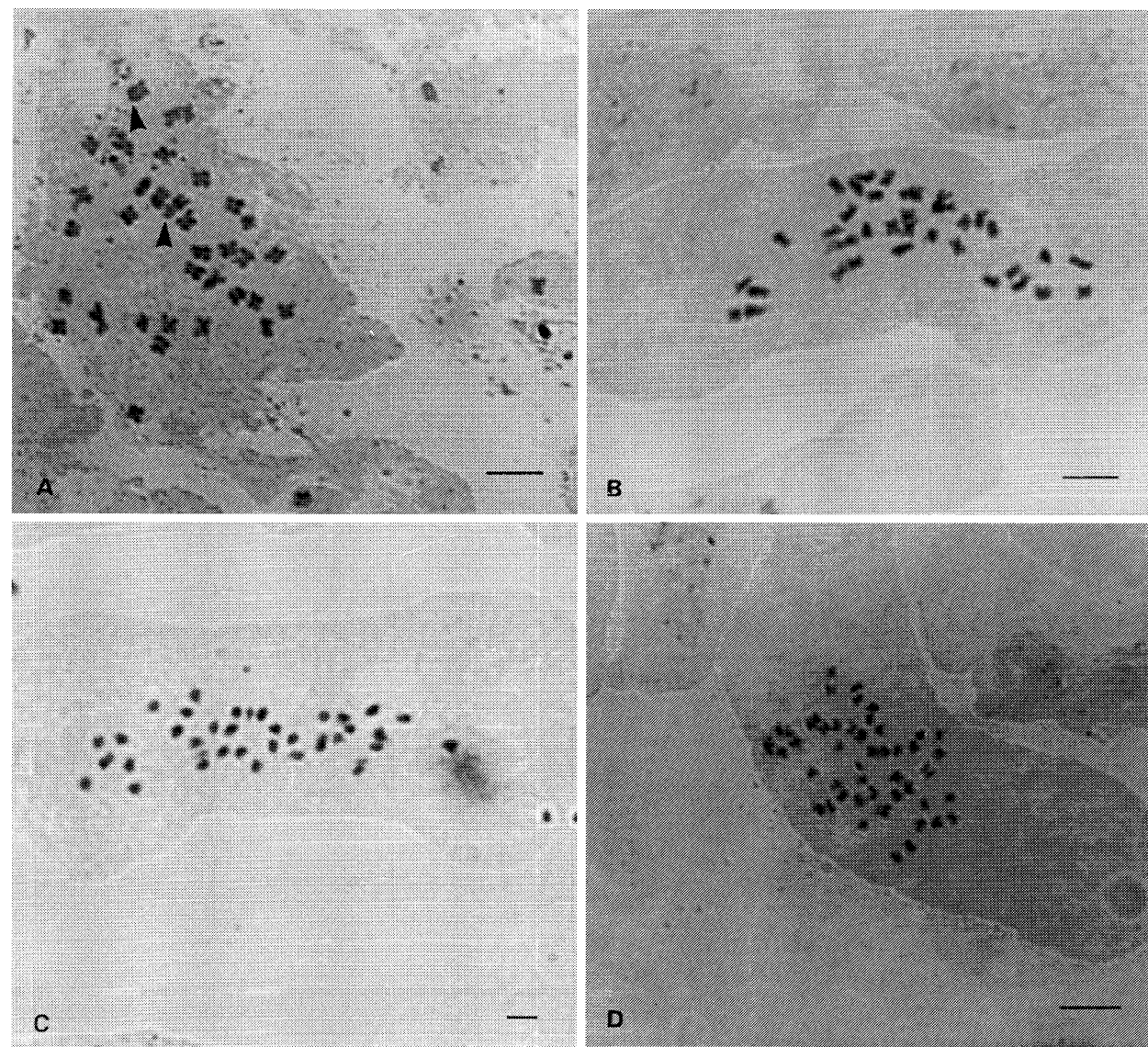

Fig. 1. Feulgen-stained somatic chromosomes in Lupinus. A) L. albescens $2 \mathrm{n}=36$, B) L. multiflorus $2 \mathrm{n}=36$, C) L. paraguariensis $2 \mathrm{n}=36$, D) L. arboreus $2 \mathrm{n}=48$. Arrows indicate satellites. Bar $=5 \mu \mathrm{m}$. 


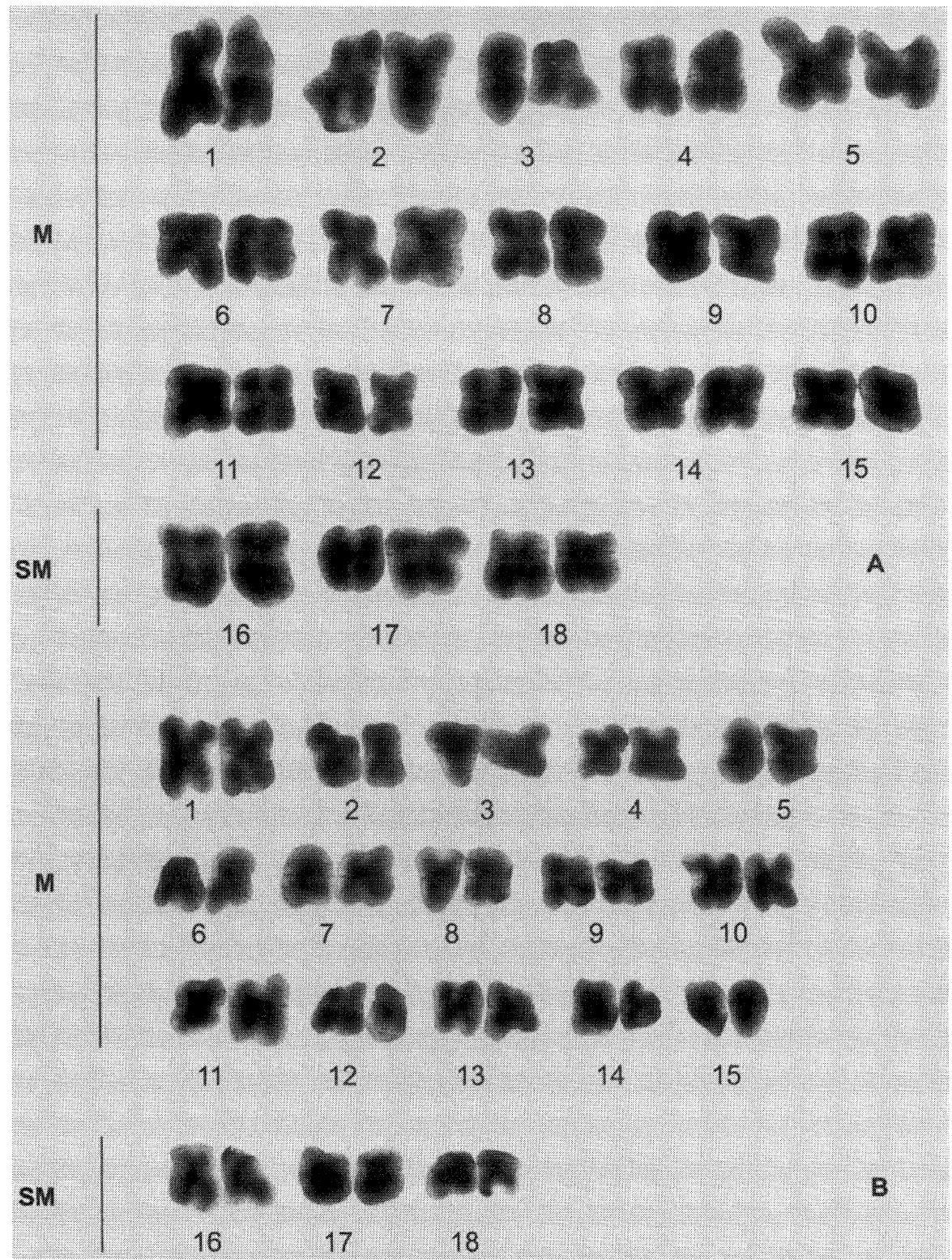

Fig. 2. Karyotypes of Lupinus albescens (A) and L. multiflorus (B).

\section{Results and discussion}

For the 3 South American species: L. albescens, L. multiflorus, L. paraguariensis we report their chromosomic numbers for the first time, as well as the karyotype for 2 of them (L. albescens, L. multiflorus), at the same time we confirm a previous cited chromosomic number for $L$. arboreus.

L. albescens: $2 \mathrm{n}=36$ (Fig. 1A), presents 15 pairs of metacentric $(\mathrm{m})$ and 3 pairs of submetacentric ( $\mathrm{sm}$ ) chromosomes. Satellites are attached to the short arms of the $\mathrm{m}$ chromosomic pair one and to the long arms of the sm chromosomic pair 16 (Fig. 2A). The size of chromosomes varies from 1.17 to $2.87 \mu \mathrm{m}$. The arm ratios range between 1.04 and 2.76 . The centromeric indexes vary from 21.54 to 50.56 . The total length of the chromosomic complement is $67.25 \mu \mathrm{m}$.

L. multiflorus: $2 \mathrm{n}=36$ (Fig. 1B), presents 15 pairs of metacentric and 3 pairs of submetacentric 
chromosomes (Fig. 2B). The size of chromosomes varies from 0.99 to $1.95 \mu \mathrm{m}$. The arm ratios range between 1.00 and 2.83 . The centromeric indexes vary from 22.35 to 50.61 . The total length of complement is $47.27 \mu \mathrm{m}$.

L. paraguariensis: $2 \mathrm{n}=36$ (Fig. 1C). The report for the first time of $2 \mathrm{n}=36$ for this species confirm the close relationship with $L$. albescens and L. multiflorus discussed by Planchuelo and Dunn (1984).

For L. arboreus (Fig. 1D) we confirm previous reports of $2 n=48$ (Federov 1974). The size of chromosomes varies from 0.93 to $1.91 \mu \mathrm{m}$. The arm ratio ranges between 1.07 and 2.98. The centromeric index varies from 25.12 to 48.37 . The total length of the chromosomic complement is $57.04 \mu \mathrm{m}$.

The somatic number $2 n=36$ reported in this study for the 3 South American species of Lupinus agrees with the ones stated for L. texensis Hook., L. subcarnosus Hook. and L. tassilicus Maire (Federov 1974) from North America; and therefore, this number appears to be more commonly found than the reported by Dunn (1984).

Since this genus shows an uncleared taxonomy and its phylogenetic relationships is partially known, it is important to continue these studies.

\section{Acknowledgments}

This study was carried out by financial support of SECyT (UNCba) and CONICOR. The authors wish to thank Ing. Agr. Diana Manero for the critical review of the manuscript.

\section{References}

Bisbi, F. A. 1981. Genisteae. In: Polhill, R. M. and Raven, P. H. (eds.). Advances in Legume Systematics. Royal Botanic Gardens, Kew.

Carstairs, S. A., Buirchel, B. J. and Cowling, W. A. 1992. Chromosome number, size and interspecific crossing ability of three Old World lupins, Lupinus princei Harms, L. atlántica Gladstones and L. digitatus Forskal, and implications for cyto-systematic relationships among the rough-seeded lupins. J. Roy. Soc. West. Aust. 75: 83-88.

Cerrate, A. and Camarena, F. 1981. Agronomía, Mejoramiento Genético, Semillas e Informe de Avance de Investigación en "tarwi” (Lupinus mutabilis Sweet) en la UNA La Molina (1974-1979). Ed. Univ. Nac. Agraria La Molina. Lima, Perú.

Dunn, D. B. 1984. Genetic Resources Cytotaxonomy and Distribution of New World Lupin Species. III ${ }^{\text {rd }}$ International Lupine Conference.

Federov, A. 1974. Chromosome Numbers of Flowering Plants. Otto Koeltz Science Publishers, Koenigstein, Germany.

Gladstones, J. S. 1974. Lupins of the Mediterranean Region and Africa. Western Australian Department Agriculture Technical Bulletin Number 26: $1-48$.

Goldblatt, P. 1981. Cytology and the Phylogeny of the Leguminosae. In: Polhill, R. M. and Raven, P. H. (eds.). Advances in Legume Systematics Part 2. Royal Botanic Gardens, Kew. pp. 427-463.

— and Johnsons, D. E. 1990. Index To Plant Chromosome Numbers 1986-1987. Missouri Botanical Garden, USA.

- and - 1991. Index To Plant Chromosome Numbers 1988-1989. Missouri Botanical Garden, USA.

- and - 1994. Index To Plant Chromosome Numbers 1990-1991. Missouri Botanical Garden, USA.

— and - 1996. Index To Plant Chromosome Numbers 1992-1993. Missouri Botanical Garden, USA.

Levan, A., Fredga, K. and Sandberg, A. A. 1964. Nomenclature for centromeric position on chromosomes. Hereditas 52: 201-220.

Lopez-Bellido, L. 1994. The Role of Legume Crops in Sustainable Agriculture. The Case of Lupin. In: Neves Martins, J. M. and Beirão da Costa, M. L. (eds.). Advances in Lupin Research. ISSA-Press. Lisboa. pp. 272-289.

Planchuelo, A. M. 1994. Wild Lupins Distribution and Its Implication as Germoplasm Resources, In: Neves Martins, J. M. and Beirão da Costa, M. L. (eds.). Advances in Lupin Research. ISSA-Press. Lisboa. pp. 65-69.

— and Dunn, D. 1984. The simple leaves Lupinus of Argentina and their relatives. Ann. Missouri Bot. Garden 71(1): 42-103. 